\title{
VALIDASI MODEL TRANSFER PENGETAHUAN DARI PERGURUAN TINGGI KE INDUSTRI KECIL
}

\author{
RETNO INDRIARTININGTIAS \\ Jurusan Teknik Industri, Universitas Trunojoyo Madura \\ E-mail: retnoTMIITB@gmail.com
}

\begin{abstract}
ABSTRAK
Penelitian sebelumnya telah dibangun efektivitas model transfer pengetahuan dari Universitas ke Industri Kecil. Model ini divalidasi dengan wawancara dengan pakar dari Universitas Trunojoyo dan pemilik Industri Kecil di Bangkalan. Penelitian ini memvalidasi penelitian yang sebelumnya secara kuantitatif dengan menggunakan kuesioner. Validasi dilakukan di Trunojoyo University dan Industri Kecil di Bangkalan. Penelitian ini menggunakan 22 proses ditransfer. Berdasarkan analisis unit, ada dua jenis responden: (1) 22 dosen sebagai sumber transfer pengetahuan, (2) 4 industri kecil sebagai penerima transfer pengetahuan. Data dihitung dengan menggunakan SEM PLS berbasis. Dari hasil perhitungan, faktor yang paling yang mempengaruhi efektivitas transfer pengetahuan dari University untuk Industri Kecil adalah arah transfer pengetahuan, ketersediaan penerima, bentuk pengetahuan, sistem informasi dan hubungan pribadi. Ada hubungan antara variabel endogen sebagai model sebelumnya. Hanya ada hubungan yang signifikan hubungan antara karakteristik lingkungan dan karakteristik penerima.
\end{abstract}

Kata kunci: pengetahuan, transfer pengetahuan, universitas, industri kecil, SEM berbasis PLS

\begin{abstract}
Previous research was built the effectiveness of knowledge transfer model from University to Small Industrywas build. The model was validated by interviews with expert from Trunojoyo University and the owner of Small Industry in Bangkalan. This research is validating the previous ones quantitatively by using questioner. Validation was done in Trunojoyo University and Small Industry in Bangkalan. This research used 22 processes transfered. Based on unit analysis, there were two kind of respondents: (1) 22 lecturers as resource of transfer knowledge, (2) 4 small industries as receiver of transfer knowledge. Data was calculated using SEM based PLS. From the calculation, the most factors that affect the effectiveness of knowledge transfer from University to Small Industries are direction of knowledge transfer, availability of receiver, form of knowledge, information system and personal relationship. There are relationships between endogenous variable as previous model. There was only an insignificant relationship that was relationship between environment characteristic and receiver characteristic.
\end{abstract}

Key words: knowledge, transfer knowledge, university, small industries, SEM based PLS

\section{PENDAHULUAN}

Transfer pengetahuan merupakan proses transmisi berorientasi tujuan dari individu, grup atau suatu organisasi kepada individu, grup atau organisasi yang lain (Weissenberg \& Spieth, 2006). Sedangkan menurut Wilkesmann et al. (2007) transfer pengetahuan adalah proses transfer tacit dan explicit pengetahuan dalam interaksi antara grup.

Transfer pengetahuan dapat didukung oleh faktor individu dan organisasi. Faktor individu menurut Grunfeld et al. (2000), Almeida dan Kogut (1999) adalah pergerakan personil. Ketika anggota suatu grup berpindah ke grup yang lain akan dimungkinkan akan terjadi transfer tacit knowledge sebaik explicit knowledge (Wilkesmann, 2007). Cohen dan Levinthal
(1990); Sulanzki (1996) dan (2000); Sulanzki et al. (2002) berpendapat bahwa tidak hanya personal, namun karakteristik organisasi juga penting bagi transfer pengetahuan. Transfer pengetahuan akan berkembang baik jika diserta dengan kontak sosial secara langsung (Wilkesmann, 2007). Dalam konteks peningkatan daya saing, penguasaan pengetahuan adalah faktor penting untuk mendongkrak daya saing (Khalil, 2000). Suatu perusahaan/organisasi akan memiliki daya saing yang baik jika memiliki penguasaan akan pengetahuan yang baik pula (Khalil, 2007). Penguasaan pengetahuan inilah yang kurang dimiliki oleh Industri Kecil di Indonesia sehingga menjadi kelemahan terbesar Industri Kecil di Indonesia (Muttaqien, 2006). 
Karya tulis ini merupakan karya tulis lanjutan dari penelitian sebelumnya. Dalam karya tulis ini dilakukan validasi model dengan cara menyebarkan kuesioner kepada dosen universitas Trunojoyo selaku sumber pengetahuan dan industri kecil Bangkalan selaku penerima transfer pengetahuan. Tujuan penelitian yang pertama adalah mengidentifikasikan faktor-faktor penting yang mempengaruhi keefektifan transfer pengetahuan dari Perguruan Tinggi ke Industri Kecil, sedangkan tujuan yang kedua adalah menganalisis hubungan antar konstruk keefektifan transfer pengetahuan dari Perguruan Tinggi ke Industri Kecil. Dengan adanya karya tulis ini diharapkan dapat membantu Industri Kecil dalam memanfaatkan serta mengembangkan pengetahuan yang diperoleh. Secara tidak langsung ini akan membantu Industri Kecil dalam membangun dan meningkatkan daya saingnya dalam perekonomian nasional.

\section{METODE}

Karya tulis ini termasuk dalam pengujian hipotesis karena bertujuan untuk menjelaskan pengaruh dari suatu hubungan tertentu yaitu pengaruh variabel-variabel transfer pengetahuan terhadap keefektifan transfer pengetahuan. Dalam hal ini, penelitian akan dimulai dengan mempelajari sejumlah teori tentang faktor kunci transfer teknologi dan pengetahuan dan keterkaitannya dengan faktor-faktor pembentuknya. Selanjutnya, teoriteori tersebut akan menjadi dasar untuk menyusun sejumlah hipotesis yang akan dibuktikan secara empirik.

Penelitian ini menggunakan pendekatan survey. Berdasarkan tipe penyelidikannya, karya tulis ini termasuk dalam studi korelasi karena karya tulis ini bermaksud untuk menggambarkan variabel-variabel penting yang berhubungan dengan terwujudnya transfer pengetahuan.Penelitian hanya dilakukan pada suatu periode tertentu, maka berdasarkan horison waktunya, penelitian ini termasuk dalam kelompok studi cross sectional. Penelitian akan mengambil data pelaksanaan transfer teknologi dan pengetahuan ke industri kecil yang telah dilakukan oleh dosen-dosen Universitas Trunojoyo pada tahun 2006-2008, data diperoleh dari database LPPM dan data kuesioner tahun 2009.

Model penelitian yang digunakan adalah pengembangan model penelitian oleh Indriartiningtias (2009). Model yang telah dibentuk

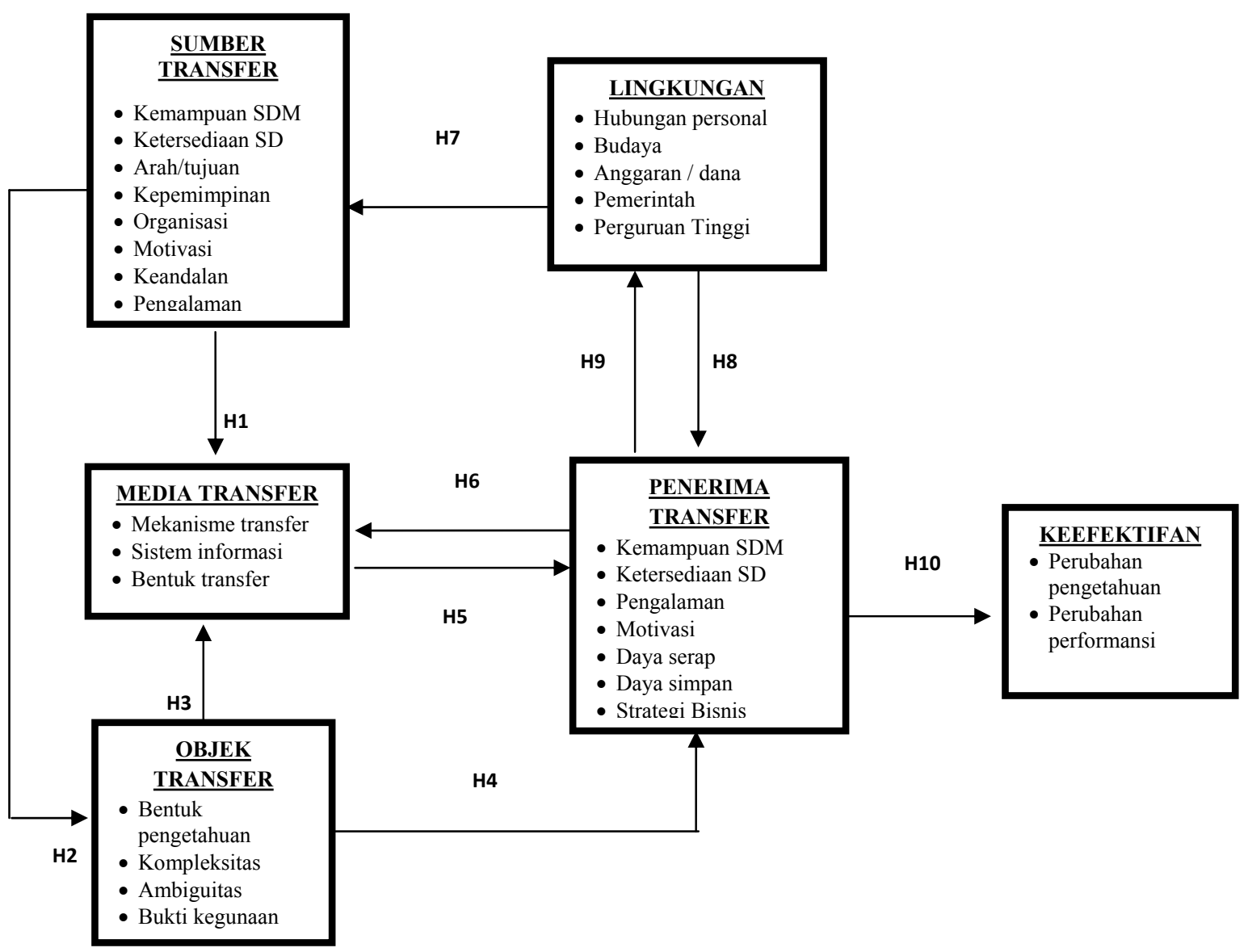

Gambar 1. Model Transfer Pengetahuan dari Perguruan Tinggi ke Induatri Kecil 
oleh Indriartiningtias (2009) masih berupa penelitian awal, belum ada proses validasi secara statistik. Indriartiningtias (2009) hanya menggunakan metode wawancara untuk membentuk model keefektifan transfer pengetahuan dari perguruan tinggi ke industri kecil. Penelitian ini merupakan penelitian lanjutan dari penelitian Indriartiningtias (2009) karena model yang telah dibentuk akan divalidasi secara statistik agar lebih dapat dibuktikan kebenarannya secara statistik.

Penelitian ini menggunakan 6 variabel endogen dan 29 variabel eksogen berdasarkan penelitian Indriartiningtias (2009). Model penelitian yang digunakan dan hipotesis penelitian ini dapat dilihat pada Gambar 1 dan Tabel 1.

Tabel 1. Hipotesis Penelitian

\begin{tabular}{cc}
\hline Hipotesis & Keterangan \\
\hline H1 & $\begin{array}{c}\text { Karakteristik Sumber Transfer mempengaruhi } \\
\text { karakteristik Media Transfer yang } \\
\text { digunakan }\end{array}$ \\
H2 & $\begin{array}{c}\text { Karakteristik Sumber Transfer mempengaruhi } \\
\text { karakteristik Objek Transfer yang } \\
\text { ditransfer }\end{array}$ \\
H3 & Karakteristik Objek Transfer mempengaruhi \\
& karakteristik Media Transfer yang \\
digunakan
\end{tabular}

Pengumpulan data dilakukan dengan tahapan: penentuan unit analisis dan responden, identifikasi responden, penentuan jumlah unit analisis, penyusunan dan penyebaran kuesioner. Klasifikasi responden dalam mengisi kuesioner dapat dilihat pada Tabel 2.

Tabel 2. Klasifikasi Responden

\begin{tabular}{ll}
\hline \multicolumn{1}{c}{ Jenis Kuesioner } & \multicolumn{1}{c}{ Responden } \\
\hline Karakteristik Sumber & Tim Dosen \\
Karakteristik Penerima & Tim Dosen \\
Karakteristik Media & Tim Dosen \\
Karakteristik Objek & Tim Dosen \\
Karakteristik Lingkungan & Tim Dosen \\
Keefektifan & Industri Kecil
\end{tabular}

Data yang telah terkumpul kemudian diolah dengan tahapan persiapan data mentah, transformasi data, verifikasi alat ukur dan pengujian hipotesis dengan SEM based PLS. Pengujian hipotesis menggunakan alat bantu software SMART PLS versi 2 .

Data survey penelitian ini menggunakan skala interval. Untuk mendapatkan data yang bernilai interval responden diminta mengisi tanda ceklist di kolom berisi pilihan nilai 1-5. Tanda ceklist yang diberikan merupakan nilai responden yang paling sesuai dengan persepsi yang responden rasakan untuk setiap pernyataan yang diajukan. Nilai 1-5 menunjukkan tingkat persetujuan responden terhadap pernyataan. Nilai 1 berkorelasi dengan pernyataan "sangat tidak setuju" sementara nilai 5 berkorelasi dengan pernyataan "sangat setuju".

\section{HASIL DAN PEMBAHASAN}

Penyebaran kuesioner dilakukan selama bulan Februari-April 2009. Penelitian ini menggunakan dua kelompok responden, yang pertama adalah Dosen UNIJOYO yang pernah masuk tim transfer teknologi dan pengetahuan ke industri kecil. Syarat ini dilihat berdasarkan pengalaman dosen dalam memenangkan dana hibah penelitian dan pengabdian pada masyarakat serta dosen yang menjadi tim pengabdian pada masyarakat pad LPPM (Database LPPM Unijoyo 2006-2008). Responden kelompok kedua adalah Industri kecil Bangkalan Madura yang telah bekerjasama dengan UNIJOYO. Banyak industri kecil di Madura yang telah bekerjasama dengan UNIJOYO. Ada 4 (empat) industri kecil yang dipilih yaitu: Industri Kecil Jamu, Industri Kecil Pengolah Salak, Industri Batik dan Industri Kecil penghasil Trasi.

Penelitian ini terdiri dari 22 (dua puluh dua) proses transfer teknologi dan pengetahuan ke industri kecil. Jumlah ini adalah jumlah keseluruhan proses transfer yang terjadi berdasarkan data tahun 2006-2008. Penelitian ini menggunakan jumlah seluruh data sebanyak 22 (dua puluh dua). Selanjutnya dilakukan pengolahan data dengan tahapan persiapan data mentah, transformasi data, verifikasi alat ukur dan pengujian hipotesis dengan SEM based PLS. Diagram Jalur model penelitian dapat dilihat pada Gambar 2.

Pada penelitian ini ada dua analisis yang akan dilakukan, yaitu analisis hubungan antara variabel eksogen dengan variabel endogen dan analisis hubungan antar variabel endogen (pengujian hipotesis).

Pada Tabel 3 dapat dilihat bahwa dari 29 variabel eksogen terdapat 2 variabel yang tidak signifikan yaitu kemampuan SDM sumber dan pengalaman 


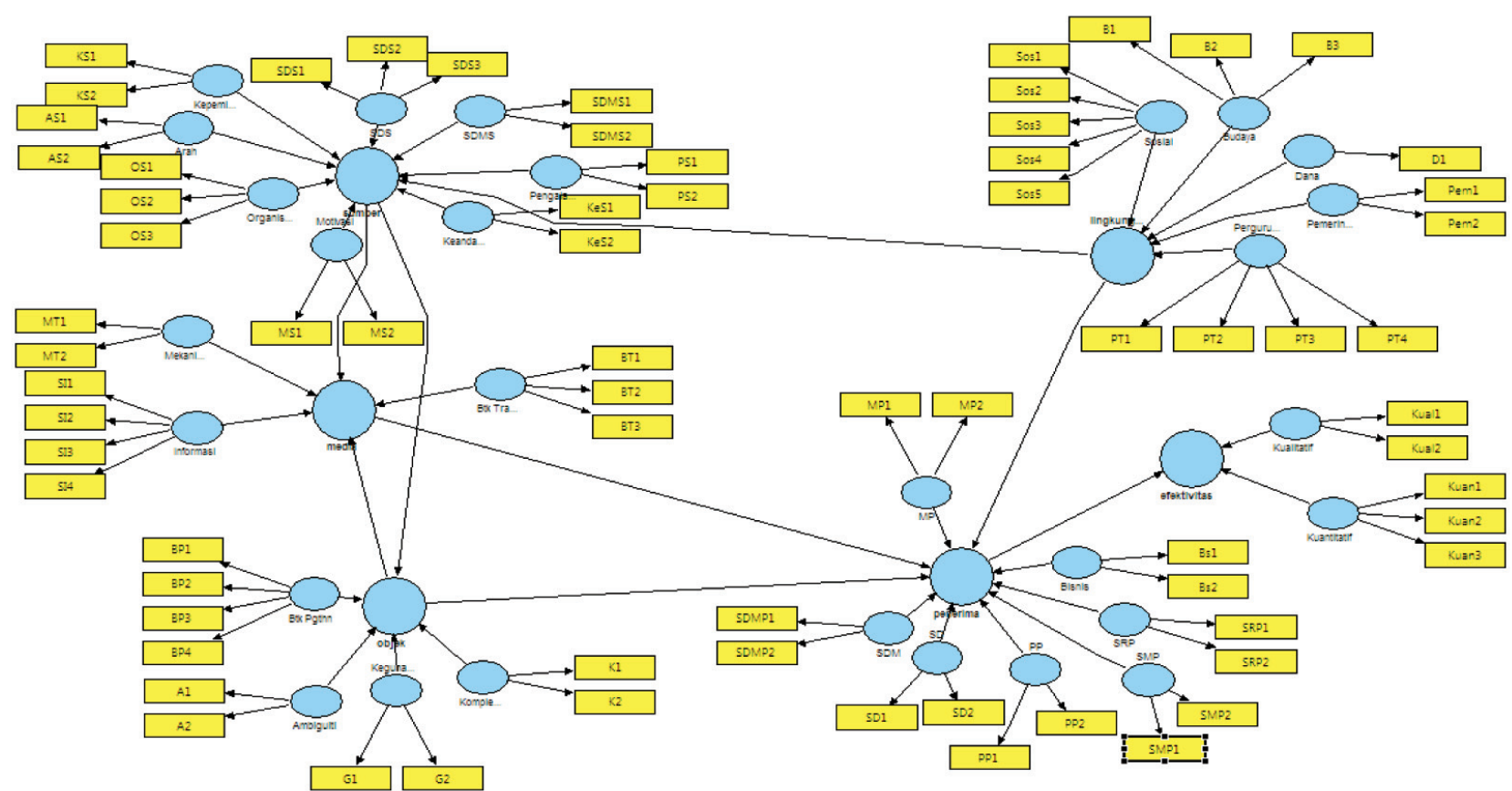

Gambar 2. Diagram Jalur Model Penelitian

Tabel 3. Hubungan Variabel Eksogen dengan Variabel Endogen

\begin{tabular}{|c|c|c|c|c|}
\hline Variabel Endogen & Variabel Eksogen & Weight & $t$ Statistic & Keterangan \\
\hline Karakteristik & Kemampuan SDM & 0,079 & 1,342 & tidak signifikan \\
\hline \multirow[t]{7}{*}{ Sumber Transfer Pengetahuan } & Ketersediaan SD & 0,174 & 5,439 & Signifikan \\
\hline & Kepemimpinan & 0,280 & 4,984 & Signifikan \\
\hline & Arah/Tujuan & 0,316 & 12,205 & Signifikan \\
\hline & Organisasi & 0,262 & 4,130 & Signifikan \\
\hline & Motivasi & 0,256 & 5,520 & Signifikan \\
\hline & Keandalan & 0,173 & 3,392 & Signifikan \\
\hline & Pengalaman & 0,127 & 3,173 & Signifikan \\
\hline \multirow{7}{*}{$\begin{array}{l}\text { Karakteristik } \\
\text { Penerima Transfer Pengetahuan }\end{array}$} & Kemampuan SDM & 0,153 & 2,280 & Signifikan \\
\hline & Ketersediaan SD & 0,355 & 5,526 & Signifikan \\
\hline & Pengalaman & 0,085 & 1,573 & tidak signifikan \\
\hline & Motivasi & 0,290 & 11,478 & Signifikan \\
\hline & Daya serap & 0,215 & 2,266 & Signifikan \\
\hline & Daya simpan & 0,233 & 5,621 & Signifikan \\
\hline & Strategi bisnis & 0,213 & 2,293 & Signifikan \\
\hline \multirow{3}{*}{$\begin{array}{l}\text { Karakteristik Media Transfer } \\
\text { Pengetahuan }\end{array}$} & Mekanisme Transfer & 0,357 & 26,956 & Signifikan \\
\hline & Sistem Informasi & 0,418 & 9,992 & Signifikan \\
\hline & Bentuk Transfer & 0,354 & 16,901 & Signifikan \\
\hline \multirow{4}{*}{$\begin{array}{l}\text { Karakteristik Objek Transfer } \\
\text { Pengetahuan }\end{array}$} & Bentuk Pengetahuan & 0,391 & 12,161 & Signifikan \\
\hline & Ambiguitas & 0,314 & 12,083 & Signifikan \\
\hline & Kegunaan & 0,305 & 6,808 & Signifikan \\
\hline & Kompleksitas & 0,236 & 7,136 & Signifikan \\
\hline \multirow{5}{*}{$\begin{array}{l}\text { Karakteristik Lingkungan Transfer } \\
\text { Pengetahuan }\end{array}$} & Personal/social & 0,353 & 8,623 & Signifikan \\
\hline & Budaya & 0,330 & 11,199 & Signifikan \\
\hline & Anggaran/dana & 0,072 & 3,305 & Signifikan \\
\hline & Pemerintah & 0,316 & 12,786 & Signifikan \\
\hline & Perguruan Tinggi & 0,206 & 9,447 & Signifikan \\
\hline \multirow[t]{2}{*}{ Efektifitas Transfer Pengetahuan } & Perubahan Pengetahuan & 0,580 & 6,076 & Signifikan \\
\hline & Perubahan Performansi & 0,686 & 6,879 & Signifikan \\
\hline
\end{tabular}


industri kecil, artinya bahwa kedua variabel tersebut bukan variabel yang menjadi karakteristik variabel endogen yang dibentuknya. Hasil ini kurang sesuai dengan hasil penelitian awal oleh Indriartiningtia (2009), berdasarkan hasil wawancara terdapat 3 variabel yang tidak mempengaruhi karakteristik variabel endogen yang dibentuknya yaitu kemampuan SDM sumber, pengalaman dan strategi bisnis industri kecil.

Tabel 4. Hubungan antara Variabel Endogen

\begin{tabular}{|c|c|c|c|c|}
\hline Hipotesis & Hubungan & $\begin{array}{c}\text { Path } \\
\text { Coefficient }\end{array}$ & $\begin{array}{c}t \\
\text { Statistic }\end{array}$ & $\begin{array}{c}R \\
\text { Square }\end{array}$ \\
\hline H1 & $\begin{array}{l}\text { sumber -> } \\
\text { media }\end{array}$ & 0,517 & 6,406 & 0,463 \\
\hline $\mathrm{H} 2$ & $\begin{array}{l}\text { sumber -> } \\
\text { objek }\end{array}$ & 0,588 & 13,466 & 0,345 \\
\hline H3 & objek -> media & 0,233 & 2,575 & 0,463 \\
\hline $\mathrm{H} 4$ & $\begin{array}{l}\text { objek -> } \\
\text { penerima }\end{array}$ & 0,398 & 8,031 & 0,715 \\
\hline H5 & $\begin{array}{l}\text { media -> } \\
\text { penerima }\end{array}$ & 0,343 & 6,084 & 0,715 \\
\hline H6 & $\begin{array}{l}\text { penerima -> } \\
\text { media }\end{array}$ & 0,564 & 9,514 & 0,577 \\
\hline H7 & $\begin{array}{l}\text { lingkungan -> } \\
\text { sumber }\end{array}$ & 0,754 & 29,584 & 0,569 \\
\hline H8 & $\begin{array}{c}\text { lingkungan -> } \\
\text { penerima }\end{array}$ & 0,251 & 5,127 & 0,715 \\
\hline H9 & $\begin{array}{c}\text { penerima -> } \\
\text { lingkungan }\end{array}$ & 0,000 & 0,000 & 0,000 \\
\hline $\mathrm{H} 10$ & $\begin{array}{r}\text { penerima -> } \\
\text { keefektifan }\end{array}$ & 0,591 & 12,615 & 0,349 \\
\hline
\end{tabular}

\section{Hipotesis 1: Karakteristik Sumber Transfer Pengetahuan Mempengaruhi Karakteristik Media Transfer Pengetahuan}

Hipotesis 1 ditunjukkan melalui hubungan Konstruk Sumber dengan Konstruk Media pada model PLS. Nilai t statistik pada hubungan ini adalah 6,406. Nilai t statistik ini berada dalam area penerimaan, yaitu berada di luar area \pm 2,080 untuk signifikansi $\alpha=0,05$ dengan $\mathrm{df}=21$. Dengan demikian, hipotesis $\mathrm{H} 1$ diterima. Artinya, karakteristik sumber terbukti secara statistik mempengaruhi karakteristik media.

Pembuktian hipotesis ini didukung oleh teori yang disampaikan oleh Bozeman (2000) dan Khalil (2000) yang menyatakan bahwa karakteristik sumber mempengaruhi karakteristik media yang digunakan dalam proses transfer. Hasil pengolahan data kuesioner menunjukkan bahwa karakteristik sumber mempengaruhi karakteristik media sebesar 0,514 > 0,3 (dari nilai weight). Nilai weight tersebut menunjukkan bahwa karakteristik sumber berpengaruh kuat terhadap karakteristik media yang digunakan dalam proses transfer.
Berdasarkan nilai $\mathrm{R}^{2}$ sebesar 0,463 yang berarti karakteristik media dapat dijelaskan oleh karakteristik sumber sebesar 46,3\%. Nilai ini tergolong bagus karena lebih besar dari 40\% (Ghozali, 2006). Teori dan hasil pengolahan data kuesioner memperlihatkan bahwa karakteristik sumber mempengaruhi karakteristik media transfer.

\section{Hipotesis 2: Karakteristik Sumber Transfer Pengetahuan Mempengaruhi Karakteristik Objek Transfer Pengetahuan}

Hipotesis 2 ditunjukkan melalui hubungan Konstruk Sumber dengan Konstruk Objek pada model PLS. Nilai t statistik pada hubungan ini adalah 13,466. Nilai t statistik ini berada dalam area penerimaan, yaitu berada di luar area \pm 2,080 untuk signifikansi $\alpha=0,05$ dengan df $=21$. Dengan demikian, hipotesis H2 diterima. Artinya, karakteristik sumber terbukti secara statistik mempengaruhi objek transfer.

Pembuktian hipotesis ini didukung oleh teori yang disampaikan oleh Bozeman (2000) dan Samirahayu (2007) yang menyatakan bahwa karakteristik sumber transfer mempengaruhi karakteristik objek yang digunakan dalam proses transfer. Hasil pengolahan data kuesioner menunjukkan bahwa karakteristik sumber mempengaruhi karakteristik media sebesar $0,588>0,3$. Nilai weight tersebut menunjukkan bahwa karakteristik sumber berpengaruh kuat terhadap karakteristik objek transfer.

Berdasarkan nilai $\mathrm{R}^{2}$ sebesar 0,345 yang berarti karakteristik objek dapat dijelaskan oleh karakteristik sumber sebesar $34,5 \%$. Nilai ini tergolong cukup bagus karena lebih besar dari $30 \%$ (Ghozali, 2006). Teori dan hasil pengolahan data kuesioner memperlihatkan bahwa karakteristik sumber mempengaruhi karakteristik objek transfer.

\section{Hipotesis 3: Karakteristik Objek Transfer Pengetahuan Mempengaruhi Karakteristik Media Transfer Pengetahuan}

Hipotesis 3 ditunjukkan melalui hubungan Konstruk Objek dengan Konstruk Media pada model PLS. Nilai t statistik pada hubungan ini adalah 2,575. Nilai t statistik ini berada dalam area penerimaan, yaitu berada di luar area $\pm 2,080$ untuk signifikansi $\alpha=0,05$ dengan $\mathrm{df}=21$. Dengan demikian, hipotesis H3 diterima. Artinya, karakteristik objek transfer terbukti secara statistik mempengaruhi karakteristik media transfer.

Pembuktian hipotesis ini didukung oleh teori yang disampaikan oleh Bozeman (2000) dan Samirahayu 
(2007) yang menyatakan bahwa karakteristik objek transfer mempengaruhi karakteristik media yang digunakan dalam proses transfer. Hasil pengolahan data kuesioner menunjukkan bahwa antara karakteristik objek dengan karakteristik media terdapat hubungan sebesar 0,233 >0,15. Nilai weight tersebut menunjukkan bahwa karakteristik objek berpengaruh kuat terhadap karakteristik objek transfer.

Berdasarkan nilai $R^{2}$ sebesar 0,463 yang berarti karakteristik media dapat dijelaskan oleh karakteristik objek sebesar 46,3\%. Nilai ini tergolong bagus karena lebih besar dari $40 \%$ (Ghozali, 2006).Teori dan hasil pengolahan data kuesioner memperlihatkan bahwa karakteristik objek mempengaruhi karakteristik media transfer.

\section{Hipotesis 4: Karakteristik Objek Transfer Pengetahuan Mempengaruhi Karakteristik Penerima Transfer Pengetahuan}

Hipotesis 4 ditunjukkan melalui hubungan Konstruk Objek dengan Konstruk Penerima pada model PLS. Nilai t statistik pada hubungan ini adalah 8,031. Nilai t statistik ini berada dalam area penerimaan, yaitu berada di luar area \pm 2,080 untuk signifikansi $\alpha=0,05$ dengan $\mathrm{df}=21$. Dengan demikian, hipotesis H4 diterima. Artinya, karakteristik objek transfer terbukti secara statistik mempengaruhi karakteristik penerima transfer.

Pembuktian hipotesis ini didukung oleh teori yang disampaikan oleh Bozeman (2000) dan Samirahayu (2007) yang menyatakan bahwa karakteristik objek transfer mempengaruhi karakteristik penerima transfer. Hasil pengolahan data kuesioner menunjukkan bahwa antara karakteristik objek dengan karakteristik penerima terdapat hubungan sebesar 0,398 >0,3. Nilai weight tersebut menunjukkan bahwa karakteristik objek berpengaruh kuat terhadap karakteristik penerima transfer.

Berdasarkan nilai $R^{2}$ sebesar 0,715 yang berarti karakteristik penerima dapat dijelaskan oleh karakteristik objek sebesar 71,5\%. Nilai ini tergolong sangat bagus karena lebih besar dari $50 \%$ (Ghozali, 2006). Teori dan hasil pengolahan data kuesioner memperlihatkan bahwa karakteristik objek mempengaruhi karakteristik penerima transfer.

\section{Hipotesis 5: Karakteristik Media Transfer Pengetahuan Mempengaruhi Karakteristik Penerima Transfer Pengetahuan}

Hipotesis 5 ditunjukkan melalui hubungan Konstruk Media dengan Konstruk Penerima pada model PLS. Nilai t statistik pada hubungan ini adalah 6,084. Nilai t statistik ini berada dalam area penerimaan, yaitu berada di luar area \pm 2,080 untuk signifikansi $\alpha=0,05$ dengan $\mathrm{df}=21$. Dengan demikian, hipotesis H5 diterima. Artinya, karakteristik media transfer terbukti secara statistik mempengaruhi karakteristik penerima transfer.

Pembuktian hipotesis ini didukung oleh teori yang disampaikan oleh Bozeman (2000) dan Khalil (2000) yang menyatakan bahwa karakteristik media transfer mempengaruhi karakteristik penerima transfer. Hasil pengolahan data kuesioner menunjukkan bahwa antara karakteristik media dengan karakteristik penerima terdapat hubungan sebesar 0,343 > 0,3 . Nilai weight tersebut menunjukkan bahwa karakteristik media berpengaruh kuat terhadap karakteristik penerima transfer.

Berdasarkan nilai $\mathrm{R}^{2}$ sebesar 0,715 yang berarti karakteristik penerima dapat dijelaskan oleh karakteristik media sebesar $71,5 \%$. Nilai ini tergolong sangat bagus karena lebih besar dari 50\% (Ghozali, 2006). Teori dan hasil pengolahan data kuesioner memperlihatkan bahwa karakteristik media mempengaruhi karakteristik penerima transfer.

\section{Hipotesis 6: Karakteristik Penerima Transfer Pengetahuan Mempengaruhi Karakteristik Media Transfer Pengetahuan}

Hipotesis 6 ditunjukkan melalui hubungan Konstruk Penerima dengan Konstruk Media pada model PLS. Nilai t statistik pada hubungan ini adalah 9,514. Nilai t statistik ini berada dalam area penerimaan, yaitu berada di luar area \pm 2,080 untuk signifikansi $\alpha=0,05$ dengan $\mathrm{df}=21$. Dengan demikian, hipotesis H6 diterima. Artinya, karakteristik penerima transfer terbukti secara statistik mempengaruhi karakteristik media transfer.

Pembuktian hipotesis ini didukung oleh teori yang disampaikan oleh Bozeman (2000) dan Samirahayu (2007) yang menyatakan bahwa karakteristik penerima transfer mempengaruhi karakteristik media transfer. Hasil pengolahan data kuesioner menunjukkan bahwa antara karakteristik penerima dengan karakteristik media terdapat hubungan sebesar 0,564 >0,3. Nilai weight tersebut menunjukkan bahwa karakteristik penerima berpengaruh kuat terhadap karakteristik media transfer.

Berdasarkan nilai $\mathrm{R}^{2}$ sebesar 0,463 yang berarti karakteristik media dapat dijelaskan oleh karakteristik penerima sebesar $46,3 \%$. Nilai ini tergolong bagus karena lebih besar dari 40\% (Ghozali, 2006).Teori dan hasil pengolahan data kuesioner memperlihatkan bahwa karakteristik penerima mempengaruhi karakteristik media transfer. 


\section{Hipotesis 7: Lingkungan Transfer Pengetahuan Mempengaruhi Karakteristik Sumber Transfer Pengetahuan}

Hipotesis 7 ditunjukkan melalui hubungan Konstruk Lingkungan dengan Konstruk Sumber pada model PLS. Nilai t statistik pada hubungan ini adalah 29,584. Nilai t statistik ini berada dalam area penerimaan, yaitu berada di luar area $\pm 2,080$ untuk signifikansi $\alpha=0,05$ dengan $\mathrm{df}=21$. Dengan demikian, hipotesis $\mathrm{H} 7$ diterima. Artinya, lingkungan transfer terbukti secara statistik mempengaruhi karakteristik sumber transfer.

Pembuktian hipotesis ini didukung oleh teori yang disampaikan oleh Bozeman (2000) dan Khalil (2000) yang menyatakan bahwa lingkungan transfer mempengaruhi karakteristik sumber transfer. Hasil pengolahan data kuesioner menunjukkan bahwa antara lingkungan dengan karakteristik sumber terdapat hubungan sebesar 0,754 >0,3. Nilai weight tersebut menunjukkan bahwa lingkungan berpengaruh kuat terhadap karakteristik sumber transfer.

Berdasarkan nilai $\mathrm{R}^{2}$ sebesar 0,569 yang berarti karakteristik sumber dapat dijelaskan oleh lingkungan sebesar 56,9\%. Nilai ini tergolong sangat bagus karena lebih besar dari 50\% (Ghozali, 2006).Teori dan hasil pengolahan data kuesioner memperlihatkan bahwa lingkungan mempengaruhi karakteristik sumber transfer.

\section{Hipotesis 8: Lingkungan Transfer Pengetahuan Mempengaruhi Karakteristik Penerima Transfer Pengetahuan}

Hipotesis 8 ditunjukkan melalui hubungan Konstruk Lingkungan dengan Konstruk Penerima pada model PLS. Nilai t statistik pada hubungan ini adalah 5,127 . Nilai t statistik ini berada dalam area penerimaan, yaitu berada di luar area $\pm 2,080$ untuk signifikansi $\alpha=0,05$ dengan $\mathrm{df}=21$. Dengan demikian, hipotesis H8 diterima. Artinya, lingkungan transfer terbukti secara statistik mempengaruhi karakteristik penerima transfer.

Pembuktian hipotesis ini didukung oleh teori yang disampaikan oleh Bozeman (2000) dan Samirahayu (2007) yang menyatakan bahwa lingkungan transfer mempengaruhi karakteristik penerima transfer. Hasil pengolahan data kuesioner menunjukkan bahwa antara lingkungan dengan karakteristik penerima terdapat hubungan sebesar $0,251>0,15$. Nilai weight tersebut menunjukkan bahwa lingkungan berpengaruh kuat terhadap karakteristik penerima transfer.

Berdasarkan nilai $R^{2}$ sebesar 0,715 yang berarti karakteristik penerima dapat dijelaskan oleh lingkungan sebesar 71,5\%. Nilai ini tergolong sangat bagus karena lebih besar dari 50\% (Ghozali, 2006). Teori dan hasil pengolahan data kuesioner memperlihatkan bahwa lingkungan mempengaruhi karakteristik penerima transfer.

\section{Hipotesis 9: Karakteristik Penerima Transfer Pengetahuan Mempengaruhi Lingkungan Transfer Pengetahuan}

Hipotesis 8 ditunjukkan melalui hubungan Konstruk Penerima dengan Konstruk Lingkungan pada model PLS. Nilai t statistik pada hubungan ini adalah 0,000 . Nilai $t$ statistik ini berada dalam area penolakan, yaitu berada di dalam area $\pm 2,080$ untuk signifikansi $\alpha=0,05$ dengan $\mathrm{df}=21$. Dengan demikian, hipotesis H9 ditolak. Artinya, karakteristik penerima transfer terbukti secara statistik tidak mempengaruhi lingkungan transfer.

Hipotesis ini berbeda dengan teori yang disampaikan oleh Bozeman (2000) dan Samirahayu (2007) yang menyatakan bahwa karakteristik penerima transfer mempengaruhi lingkungan transfer. Hubungan antara karakteristik penerima transfer dengan lingkungan transfer tidak diolah karena pada awal penyusunan diagram jalur path/hubungan karakteristik penerima transfer mempengaruhi lingkungan tidak dapat diolah lebih lanjut (path berwarna merah).

\section{Hipotesis 10: Karakteristik Penerima Transfer Pengetahuan Mempengaruhi Keefektifan dia Transfer Pengetahuan}

Hipotesis 10 ditunjukkan melalui hubungan Konstruk Penerima dengan Konstruk Keefektifan Transfer pada model PLS. Nilai t statistik pada hubungan ini adalah 12,615. Nilai t statistik ini berada dalam area penerimaan, yaitu berada di luar area $\pm 2,080$ untuk signifikansi $\alpha=0,05$ dengan $\mathrm{df}=21$. Dengan demikian, hipotesis H10 diterima. Artinya, karakteristik penerima transfer terbukti secara statistik mempengaruhi keefektifan transfer.

Pembuktian hipotesis ini didukung oleh teori yang disampaikan oleh Bozeman (2000) dan Samirahayu (2007) yang menyatakan bahwa mempengaruhi transfer. Hasil pengolahan data kuesioner menunjukkan bahwa antara karakteristik penerima transfer dengan keefektifan terdapat hubungan sebesar 0,591 >0,15. Nilai weight tersebut menunjukkan bahwa karakteristik penerima transfer berpengaruh kuat terhadap keefektifan transfer.

Berdasarkan nilai $\mathrm{R}^{2}$ sebesar 0,349 yang berarti keefektifan transfer dapat dijelaskan oleh karakteristik penerima sebesar $34,9 \%$. Nilai ini 
tergolong cukup bagus karena lebih besar dari 30\% (Ghozali, 2006). Teori dan hasil pengolahan data kuesioner memperlihatkan bahwa karakteristik penerima transfer mempengaruhi keefektifan transfer.

\section{SIMPULAN}

Berdasarkan hasil pengolahan data dan analisis statistik terhadap data penelitian, diperoleh hasil bahwa faktor-faktor yang mempengaruhi keefektifam transfer pengetahuan dari Perguruan Tinggi ke Industri Kecil antara lain pertama Karakteristik Perguruan Tinggi yang terdiri dari Ketersediaan SD Sumber, Arah/Tujuan Pelaksanaan Transfer, Kepemimpinan Sumber, Organisasi Sumber, Motivasi, Pengalaman Sumber dan Keandalan, kedua Karakteristik Industri Kecil yang terdiri dari Kemampuan SDM, Ketersedian SD, Motivasi, Daya Serap, Daya Simpan dan Strategi Bisnis, ketiga Karakteristik Media Transfer Pengetahuan yang terdiri dari Mekanisme Transfer, Sistem Informasi, dan Bentuk Transfer, keempat Karakteristik Objek Transfer Pengetahuan yang terdiri dari Bentuk Pengetahuan, Ambiguitas, Kompleksitas dan Kegunaan dan terakhir Lingkungan Transfer Pengetahuan yang terdiri dari Hubungan Personal, Budaya, Penyandang Dana/Anggaran, Perguruan Tinggi dan Pemerintah. Hubungan antar konstruk endogen secara umum terbukti secara signifikan, hanya ada satu hubungan yang tidak signifikan yaitu Karakteristik Penerima Transfer Pengetahuan tidak mempengaruhi Lingkungan Transfer Pengetahuan. Hasil ini membuktikan bahwa hanya ada satu hipotesis yang tidak terbukti yaitu Hipotesis 9 .

\section{DAFTAR PUSTAKA}

Bozeman, B. 2000. Technology Transfer and Public Policy: A Review of Research and Theory, Research Policy 29 (2000) 627-655.

Ghozali, I., Analisis Multivariat dengan Program SPSS, Badan Penerbit UNDIP, Semarang, 2005.

Hair, A, Tatham, B., 1998. Multivariate Data Analysis Fifth Edition, Prentice Hall International, Inc, USA

Indriartiningtias, R. Wiriatmaja, I.W. 2009. Perancangan Model Transfer Pengetahuan dari Perguruan Tinggi ke Industri Kecil, Jurnal Teknik Industri, UMM, Malang.

Khalil, M. T. 2000. Management of Technology: The Key to Competitiveness and Wealth Creation. McGrawHill, Singapore.

Kremer, D. 2005. Research Program on Knowledge Transfer and Exchange CRE-MS, Science of Communivation.

Lu, J.W, Beamish, P.W. 2006. SME internationalization and performance:Growth vs. Profitability. Journal International Enterpreneur 4: 27-48.

Muttaqien. 2006. Knowledge Management untuk UKM, Harian Umum Sore Sinar Harapan.

Ngoc, P.T.B. 2005. An empirical study of Knowledge Transfer within Vietnam's IT Companies. Working paper, University Hanoi, Vietnam.

Nonaka, T. 1995. The Knowledge - Creating Company, Oxford University, New York.

Staley, M. 1963. Modern Small Industry for Developing Countries, McGraw-Hill.

Wilkesmann, U., Wilkessmann, M., Alfredo, V. 2007. Requirement for Knowledge Transfer in Hospital, Discussion paper, Zentrums Fur Weiterbildung, Universitat Dortmund. 